Maria Ochoa · José Arribas

\title{
Diagenetic paths in the margin of a Triassic Basin: NW zone of the Iberian Chain, Spain
}

\begin{abstract}
Buntsandstein deposits generated in a slowly subsiding basin on the western margin of the Iberian Chain are represented by a stratigraphic succession of fluvial deposits less than $100 \mathrm{~m}$ thick (conglomerates, sandstones, and shales). Diagenetic processes in sandstones can be grouped as eodiagenetic, mesodiagenetic, and telodiagenetic. Eodiagenesis can be associated with Muschelkalk, Keuper, and probably early Jurassic times. Mesodiagenesis is probably related to Jurassic times. Diagenetic chemical reactions suggest a maximum burial less than $1.5 \mathrm{~km}$ and low temperatures $\left(<120^{\circ} \mathrm{C}\right)$. Patterns of porosity reduction by compaction and cementation suggest four diagenetic stages: (1) Loss of primary porosity by early mechanical compaction; (2) early cementation (Kfeldspar and dolomite); (3) dissolution of cements; and (4) framework collapse by re-compaction. These stages are manifested by the presence of two types of sandstone. Type I sandstones present high intergranular volume (mean, 30\%). Type II sandstones are characterized by high compactional porosity loss and exhibit low values of intergranular volume (mean, 16.9\%). Type II sandstones are associated with the dissolution of cement and later re-compaction of type I sandstones. An intermediate telodiagenetic phase is deduced and related to the sharp unconformity between Lower Cretaceous sediments and the underlying sediments. This suggests that a mechanically unstable framework collapsed during the Cretaceous, generating type II sandstones. The analyzed diagenetic paths have a wide applicability on similar marginal areas of rift basins.
\end{abstract}

M. Achoa $(\square) \cdot$ J. Arribas

Departamento de Petrología y Geoquímica, Facultad de CC. Geológicas, Universidad Complutense de Madrid, 28040 Madrid, Spain

E-mail: mochoa@geo.ucm.es

E-mail: arribas@geo.ucm.es
Keywords Sandstones - Fluvial deposits - Diagenesis · Porosity reduction - Iberian Peninsula $\cdot$ Buntsandstein

\section{Introduction}

Triassic deposits in the Iberian Chain consist of the classic Germanic facies (detrital Buntsandstein, dolomitic Muschelkalk and lutitic-evaporitic Keuper). Triassic sediments were deposited during an intracratonic rifting phase that generated NW SE trending troughs (Arche and López-Gómez 1999) (Fig. 1). Buntsandstein facies consist of fluvial red-beds mainly deposited in alluvial fan systems developed along the troughs (Sopeña and Sánchez-Moya 1997). The Triassic sequence in the Iberian Range is overlain by a thick pile ( $800 \mathrm{~m}$, approximately) of Jurassic marine carbonate deposits, which represent the postrift sequence (Aurell et al. 2002). Lower Cretaceous detrital sediments were deposited overlying a sharp erosional unconformity, after the erosion of Jurassic sequence at the margins of the Iberian Basin (Fig. 1c). This unconformity is related to a second phase of rifting which ended with the deposition of Upper Cretaceous carbonate sediments that represent a postrift period of thermal subsidence (Salas et al. 2001).

Different rates of subsidence in the Triassic Basin have produced strong lateral variations in sediment thickness. The more rapidly subsiding troughs contain more than 1,000 $\mathrm{m}$ of clastic deposits. But the Buntsandstein is barely $100 \mathrm{~m}$ thick on the western margin of the basin (Fig. 1c), and this could have influenced its diagenesis. Although the diagenesis in the others troughs has been described by several authors (Arribas 1984, 1987; Marfil and Buendía 1980; Marfil et al. 1996), little is known about these processes in the slowly subsiding marginal areas of the basin.

The aim of this paper is to describe the diagenetic processes that acted in these marginal areas of the basin and to compare them to those analyzed in the depo- 
Fig. 1 a Location of the study area on a simplified geological map of the Iberian Peninsula. b Generalized geological map of the study area showing location of stratigraphic successions (stars). c Cross-section scheme (see Fig. 1b for location), highlighting regional stratigraphic relationships between the different Permian and Mesozoic units (based on Sopeña and Sánchez-Moya 1997, Salas et al. 2001)
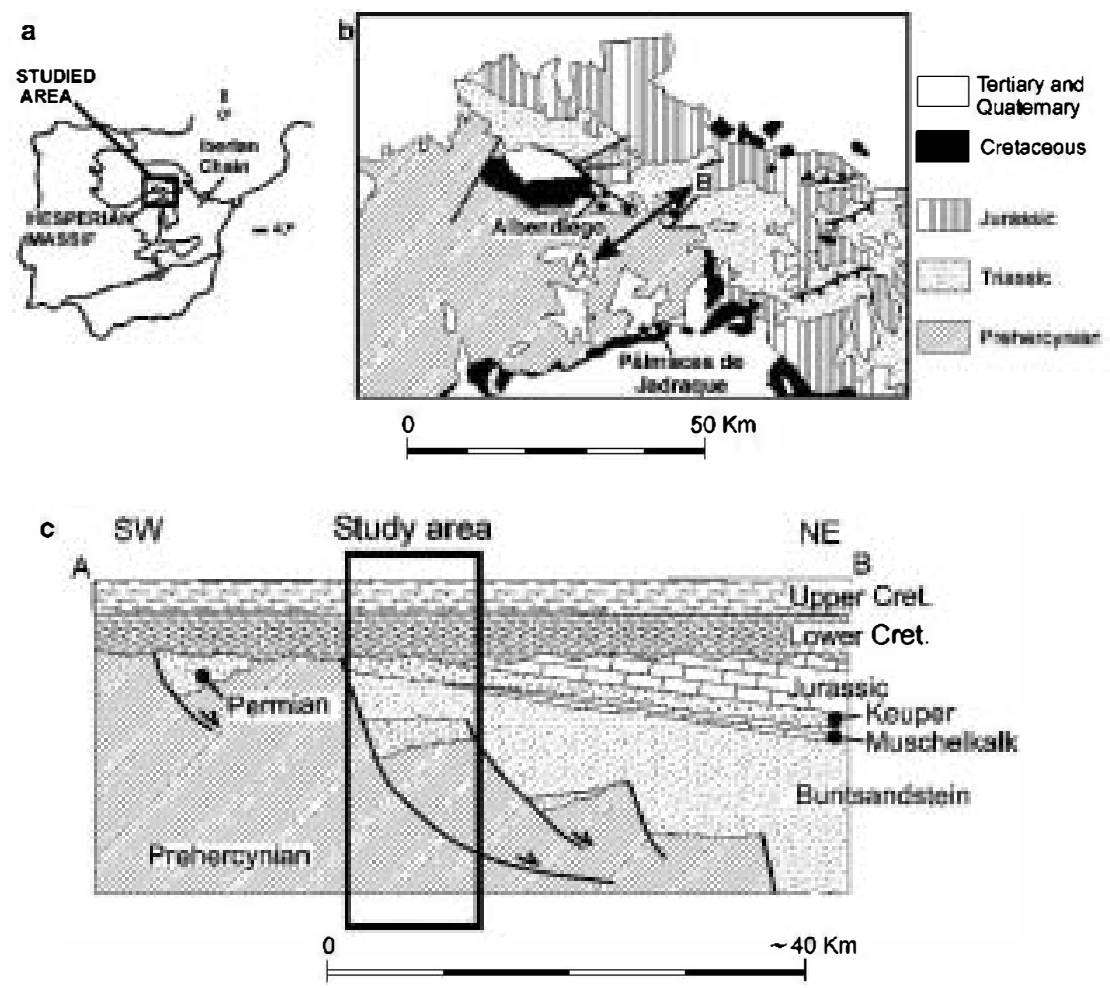

center areas. Thus, results may contribute to a general understanding of the course of diagenesis and its consequences in different areas of continental rift basins. This study is particularly concerned with the western margin of the Castellana branch of the Iberian Chain, close to Albendiego and Páhnaces de Jadraque (Guadalajara province) (Fig. 1b), where the rate of subsidence was low during formation of the Triassic Basin. Classic petrographic techniques on sandstones (optical microscopy, cathodoluminescence (CL), scanning electron microscopy) have been used. These techniques have been proven as useful tools in deciphering the diagenetic history in this part of the basin.

\section{Lithostratigraphy}

Buntsandstein deposits in the vicinity of Albendiego and Pálmaces de Jadraque $(80 \mathrm{~m}$ and $65 \mathrm{~m}$ thick, respectively) are composed mainly of arkoses associated with conglomerates and siltstones (Fig. 2). In both areas these fluvial deposits are arranged in four lithostratigraphic units (A, B, C and D), which suggests analogous depositional systems. The units are probably related to tectonic system tracts as introduced by Sopeña and Sánchez-Moya (1997). Caution must be used in correlating the stratigraphic records of Albendiego and Pálmaces de Jadraque given the discontinuity of both outcrop areas and the absence of biostratigraphic data.

Unit A consists of conglomerates and coarse-grained sandstones with metaquartzite pebbles, corresponding to the fill of low sinuosity channels. Upwards these evolve into a medium-sinuosity system (unit B) where a floodplain develops with overbank deposits and paleosols. Unit B can be divided into two subunits (B1 and B2): the first consists mainly of mudstones, and the second of channeled sandstone facies and calcrete paleosols. Unit $\mathrm{C}$ consists of sandstones with interbedded mudstone associated with stacked low-sinuosity channels in which sinuosity increases upwards. In addition, floodplain deposits become more important at the top of the unit. Finally, unit D is composed mainly of clayey siltstones (floodplain deposits) with interbedded finegrained sandstones.

\section{Methods}

Mainly common petrographic methods were used to analyze sandstones. Thin sections were etched and stained using $\mathrm{HF}$ and sodium cobaltinitrite solution for $\mathrm{K}$-feldspar identification, and alizarin-red and potassium ferrocyanide solution for carbonate identification (Chayes 1952; Lindholm and Finkelman 1972, respectively). The modal composition of 38 samples (Fig. 2) was determined by point-counting thin sections using the Gazzi-Dickinson method (Zuffa 1985). A total of 400 points were counted per slide, including framework and intergranular space components (Table 1). Electron microprobe and scanning microprobe analyses were also performed. Cathodoluminescence examination was carried out to identify different phases of carbonate cementation. 


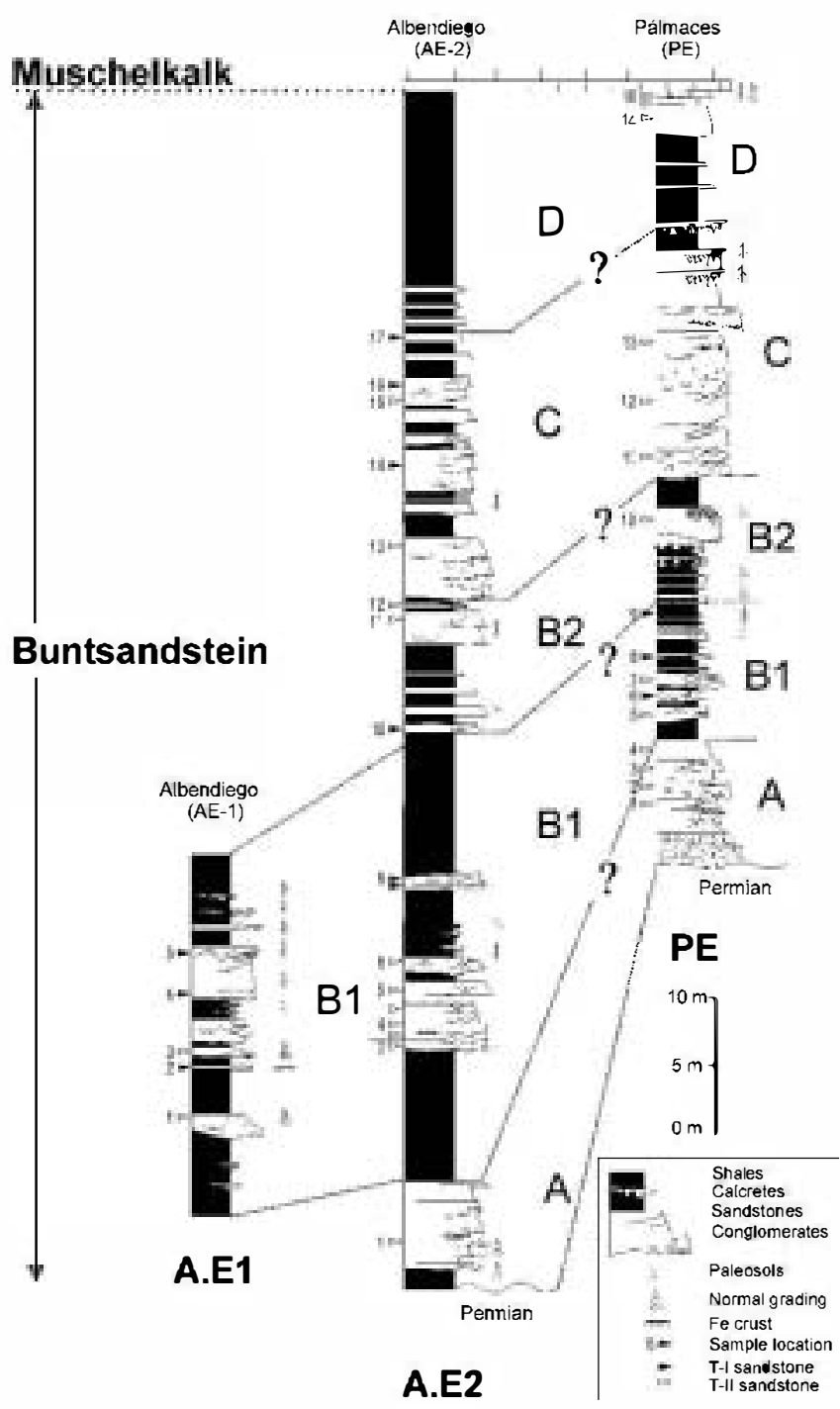

Fig. 2 Stratigraphic successions of the Buntsandstein from Albendiego (AEl and AE2) and Pálmaces de Jadraque (PE) localities. A, $\mathrm{B} 1, \mathrm{~B} 2, \mathrm{C}$ and $\mathrm{D}$ indicate the lithos atigraphic units

\section{Detrital composition of sandstones}

Modal composition of sandstones from the Buntsandstein is summarized in Table 1 . They are arkoses with very little content in rock fragments (Fig. 3a). Quartz grains are dominantly monocrystalline, and $\mathrm{K}$-feldspar appears as the dominant feldspar over trace amounts of plagioclase found in some samples from the Albendiego section. Rock fragments are very scarce (mainly $<1 \%$ ), and correspond to low-grade metamorphic (slate schists) and metasediments (phyllites and fine grained sandstones) grains. Other framework components are micas (biotite and muscovite), dense minerals (mainly tourmaline) and intraclasts (carbonate and argillaceous), present in percentages $<5 \%$. Slight differences can be established between sand composition from each lithostratigraphic unit (Fig. 3b). The basal unit (unit A) contains the lowest means in $\mathrm{K}$-feldspar $\left(\mathrm{Q}_{65} \mathrm{~F}_{34} \mathrm{R}_{1}\right)$, while unit $\mathrm{B} 1$ shows the highest content $\left(\mathrm{Q}_{52} \mathrm{~F}_{46} \mathrm{R}_{2}\right)$.

The provenance of Buntsandstein deposits in the Iberian Chain has been related to the erosion of coarsegrained rocks (granitoids and gneisses) from the Hesperian Massif because of their quartzofeldspathic petrofacies (from $\mathrm{Q}_{40} \mathrm{~F}_{56} \mathrm{R}_{4}$ to $\mathrm{Q}_{93} \mathrm{~F}_{7} \mathrm{R}_{\mathbf{0}}$; Arribas et al. 1985). A progressive decrease in feldspar toward the southeast (distal and depocentral areas of the basin) is observed (Arribas et al. 1985). Thus, the northwestern marginal zones represent the proximal areas of the basin, exhibiting the highest content in feldspar grains (mean of $\mathrm{Q}_{58} \mathrm{~F}_{41} \mathrm{R}_{1}$ in this study).

\section{Diagenetic processes}

\section{Compaction}

Mechanical compaction can be petrographically quantified following traditional methods (Rittenhouse 1971; Beard and Weyl 1973). Rittenhouse (1971) assesses this process by estimation of original porosity loss, considering the amount of ductile grains. According to Beard and Weyl (1973), the original porosity depends on framework sorting. The analyzed sandstones range widely in size, but the sorting is similar for all (mainly well sorted, Table 1). The estimated original porosity of sandstones with this degree of sorting is approximately 40\% (Table 3 in Beard and Weyl 1973). Deformed ductile grains (micas, argillaceous to silty rip-up clasts and rock-fragments; mean of $5.6 \%$ of sandstone framework) produced a loss of original porosity by mechanical compaction ranging from $3 \%$ to $7 \%$ (Rittenhouse 1971). These values are slightly lower than those reported in depocentral areas of the Aragonese branch of the Iberian Chain (mean of $10 \%$; Arribas and Soriano 1984), probably due to a greater amount in intrabasinal soft grains in distal deposits.

Porosity loss by chemical compaction can be estimated by the method of Mitra and Beard (1980). This method is based on the estimation of vertical shortening of grains. This shows that the sandstones have lost approximately $5 \%$ of porosity by pressure-solution. Greater values were reported by Arribas and Soriano (1984) in the Aragonese branch of the Iberian Chain, and Marfil et al. (1996) in the Castilian branch ( $812 \%$ and $6 \mathbf{9 \%}$, respectively).

Houseknecht (1987) and Lundegard (1992) assessed the impact of compaction taking into account the intergranular volume of the original sediment and its reduction during diagenesis. The differences between rough methods (Rittenhouse 1971; Beard and Weyl 1973; Mitra and Beard 1980) and the Lundegard (1992) method show that compaction processes have been underestimated by classic methods. The method of Lundegard (1992) is based on more objective petrographic parameters and is therefore more reliable with 
respect to porosity reduction. Porosity loss by compaction (COPL, Lundegard 1992) in the analyzed sandstones ranges from $1.4 \%$ to $35.2 \%$ (Table 1 ). These values include both mechanical and chemical compaction processes.

\section{Cements and replacements}

Several diagenetic precipitates occur in the Buntsandstein sandstones occluding intergranular pore space. Some of these diagenetic phases also replace framework components or even other cements. The common diagenetic minerals are: quartz, K-feldspar, dolomite, calcite and clay minerals (illite and kaolinite).

\section{Quartz}

This cement appears as thin overgrowths around detrital grains, and sometimes includes other earlier diagenetic phases such as clay mineral pore lining or hematite coatings (Fig. 4a, b). Quartz cement frequently appears corroded by other cements (i.e. late dolomite). It is mainly developed towards the top of the stratigraphic section, attaining a maximum value of $4.5 \%$ of total rock volume (mean, $0.6 \%$ ). Petrographic evidence suggests that quartz cement is one of the latest cement phases during burial diagenesis. For instance, quartz cement adapts to the euhedral forms of feldspar cement and therefore postdates it (Fig. 4c).

Many authors have pointed out that in most sedimentary basins this cement precipitates at depths $>2.5 \mathrm{~km}$ and temperatures above $80^{\circ} \mathrm{C}$ (Giles et al. 1992; Gluyas et al. 1993; Worden and Morad 2000; Walderhaug et al. 2001). However, small amounts of quartz cement have been inferred during shallow burial depths $(<1.5 \mathrm{~km})$ and temperatures as low as $40^{\circ} \mathrm{C} 60^{\circ} \mathrm{C}$ (Haszeldine et al. 1984; Burley et al. 1989). It seems reasonable to assume low temperature and depth for quartz cementation in Buntsandstein sandstones due to the scarce development of this cement. In addition, an internal source of silica is deduced by the presence of slightly developed pressure-solution processes.

\section{K-feldspar}

This cement occurs as euhedral overgrowths, filling grain fractures and grain dissolution pores (Fig. 4c). This cement is commonly corroded and replaced by dolomite. K-feldspar cement is quantitatively more important than quartz cement (mean, $1 \%$ ), occasionally attaining $5 \%$ of total rock volume, and appearing in all lithostratigraphic units. Composition is near pure orthoclase (mean, Or, ${ }_{7} \mathrm{Ab}_{3} \mathrm{An}_{0}$ ) and differs little from the composition of detrital nuclei. This cementation can be placed chronologically before quartz cement and early dolomite cement (Fig. 4d). These facts, combined with the high degree of idiomorphism, indicate early precipitation during eodiagenetic environments (Arribas 1987).

\section{Dolomite}

This cement exhibits a poikilitic texture, occluding porosity completely (Fig. 4d). Its content varies from $0.2 \%$ to $35 \%$ of total rock volume. The highest percentages of dolomite cement appear on sandstones from unit B1 and at the top of the Albendiego stratigraphic succession. In both cases, sandstones are mainly thin bedded $(<1 \mathrm{~m})$ and associated to paleosols. Two phases of dolomite cementation can be distinguished from petrographic evidences: (1) early dolomite, corresponding to a pre-compaction cement but postdating $\mathrm{K}$-feldspar cement, and (2) a late dolomite, which is post-compaction and post-quartz cementation. In addition, CL differs strongly between the two phases. Early dolomite is not luminescent (Fig. 4e) suggesting precipitation under active fresh water phreatic oxidizing conditions (Tucker 1988). Quartz cement and pseudomatrix are scarce when early dolomite is present, due to inhibition of quartz cementation and compaction by dolomite cement. Nevertheless, the presence of $\mathrm{K}$-feldspar cement is not dependent of early dolomite cement (Fig. 4f). These features support the assumption that this dolomite phase is an early (eodiagenetic) cement. In other areas of the basin, the formation of eodiagenetic dolomite has been related to calcrete paleosols or to arid sedimentation environments during Muschelkalk transgression (Arribas 1984, 1987; Morad et al. 1989; Marfil et al. 1996). In contrast, the late dolomite has an intense bright orange CL that can be explained by anoxic conditions during precipitation (Machel 1985; Tucker 1988). This dolomite phase frequently replaces $\mathrm{K}$-feldspar grains and their overgrowths, and corrodes quartz and clay minerals. These textures support the late precipitation of dolomite, which is considered the latest cement formed during burial of the studied sediments (mesodiagenetic stage).

\section{Calcite}

This cement occurs as isolated crystals and equigranular anhedral mosaics, occasionally with many hematite impurities. Calcite cement occupies a high percentage of intergranular volume (from $\mathbf{0 . 5 \%}$ to $25.3 \%$, mean $9 \%$ ). Sandstones with this type of cement show little rock compaction (high intergranular volume and little pseudomatrix). Such sandstones have a framework showing compaction and textural relationships similar to those in sandstones with dolomite cement. These textures suggest an origin of calcite cementation related to dedolomitization processes. Hematite impurities maintain the outline of precursor rhombohedral crystals of dolomite. Calcite is not luminescent under CL, which suggests shallow oxidizing conditions during diagenesis. Dedo- 
Table 1 M•dal comp•sition of Buntsandstein sandstønes

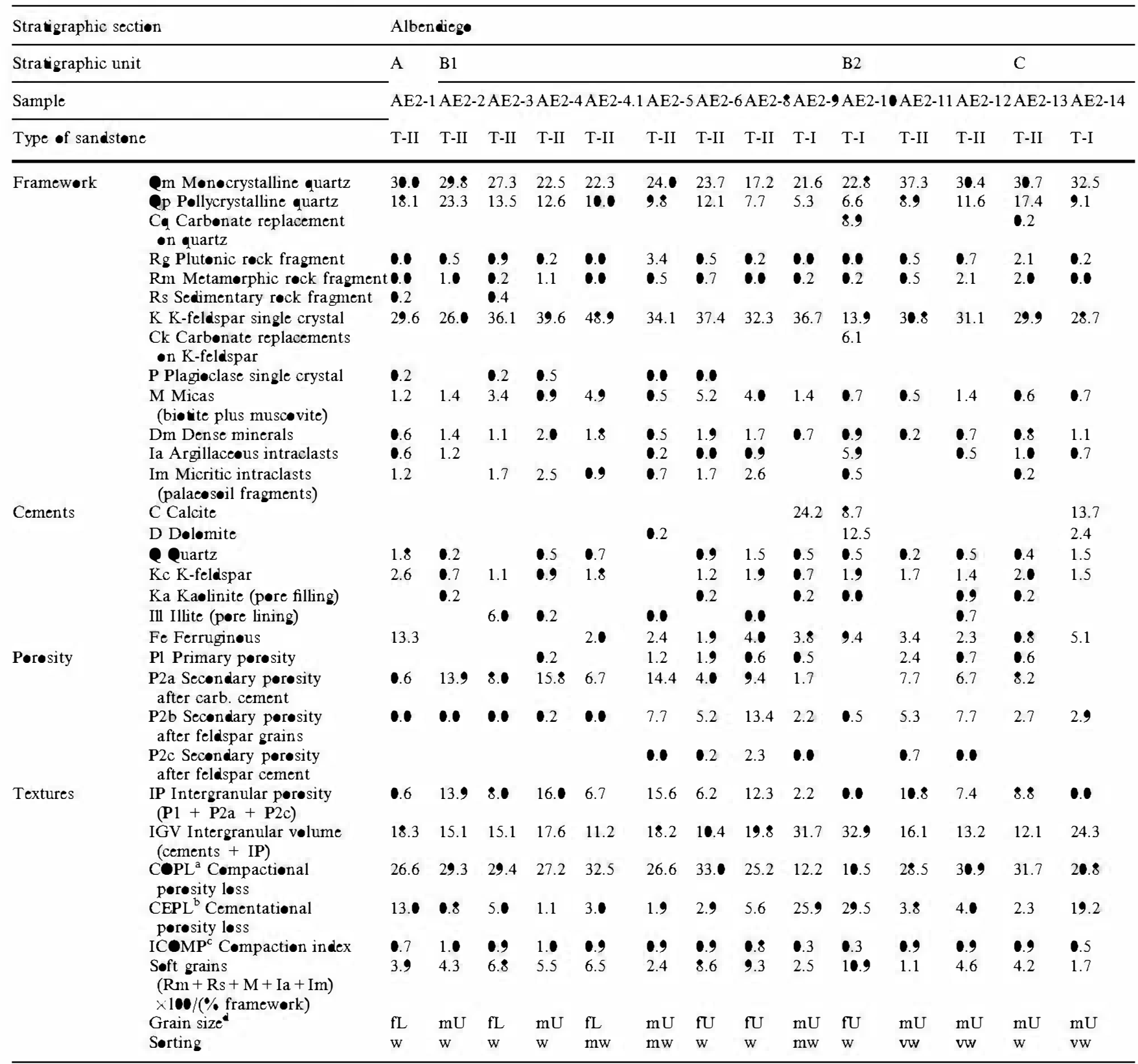

0. trace amounts

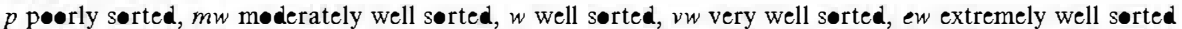

$\left.{ }^{2} \mathrm{COPL}=\mathrm{Pi}-((100-\mathrm{Pi}) \times \mathrm{IGV}) /(100-\mathrm{IGV})\right) ; \mathrm{Pi}$ riginal p॰rısity (estimated) $=40 \%$

${ }^{\mathrm{b}} \mathrm{CEPL}=(\mathrm{Pi}-\mathrm{COPL}) \times($ cements/IGV)

${ }^{\mathrm{C}} \mathrm{ICOMP}=\mathrm{COPL} /(\mathrm{COPL}+\mathrm{CEPL})$

'fL $62-88 \mu$; fU 88-125 $\mu$; fL 125-177 $\mu$; fU 177-250 $\mu$; mL 250-35 $\mu$; mU 350-500 $\mu$; crsL 500-710 $\mu$

lomitization could have been caused by meteoric water influx during telodiagenesis (Groot 1967; Marfil and Buendia 1980; Morad et al. 1990, 1995).

\section{Hematite}

Hematite cement occurs in oxidizing conditions as coatings around the detrital grains, or as secondary pore filling. Also, the hematite cement appears as a product of dedolomitization of $\mathrm{Fe}$-rich dolomite at shallow depths
(Morad et al. 1995). Its occurrence is very variable (maximum percentage $13.6 \%$, mean $4 \%$ ). Two generations can be deduced: an earlier generation, which is a continuous coating included in the earliest diagenesis, and a later generation, which fills secondary porosity.

\section{Clay minerals}

Kaolinite is mainly present as cement or occasionally as replacement of $\dot{\mathrm{K}}$-feldspar in sandstones, generating a 
B1 A $\quad$ B1 B2 C

$\mathrm{D}$

AE2-15 AE2-16 AE2-17 AE1-1 AE1-2 AE1-3 AE1-4 AE1-5PE-1PE-2PE-3PE-4PE-5PE-6PE-7PE-8PE-9PE-10PE-11PE-12PE-13PE-14PE-15PE-16

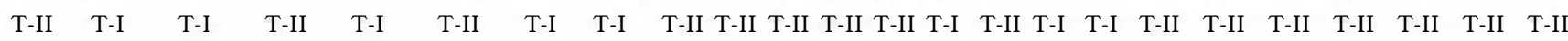

\begin{tabular}{|c|c|c|c|c|c|c|c|c|c|c|c|c|c|c|c|c|c|c|c|c|c|c|c|}
\hline $\begin{array}{l}25.9 \\
12.7\end{array}$ & $\begin{array}{l}21.6 \\
9.9\end{array}$ & $\begin{array}{l}19.3 \\
6.0 \\
9.2\end{array}$ & $\begin{array}{l}29.7 \\
13.3\end{array}$ & $\begin{array}{l}20.1 \\
13.2\end{array}$ & $\begin{array}{l}21.0 \\
18.7\end{array}$ & $\begin{array}{l}19.3 \\
8.7\end{array}$ & $\begin{array}{l}23.6 \\
16.0 \\
2.4\end{array}$ & $\begin{array}{l}43.6 \\
14.0\end{array}$ & $\begin{array}{l}51.2 \\
12.6\end{array}$ & $\begin{array}{l}41.4 \\
12.9\end{array}$ & $\begin{array}{l}36.7 \\
7.7\end{array}$ & $\begin{array}{l}45.9 \\
2.7\end{array}$ & $\begin{array}{l}42.8 \\
4.9\end{array}$ & $\begin{array}{l}42.1 \\
6.7\end{array}$ & $\begin{array}{l}28.1 \\
4.6\end{array}$ & $\begin{array}{l}28.1 \\
9.7\end{array}$ & $\begin{array}{l}36.8 \\
9.9\end{array}$ & $\begin{array}{l}31.8 \\
16.4\end{array}$ & $\begin{array}{l}46.1 \\
4.6\end{array}$ & $\begin{array}{l}49.3 \\
4.2\end{array}$ & $\begin{array}{l}27.4 \\
7.8\end{array}$ & $\begin{array}{l}9.4 \\
2.0\end{array}$ & $\begin{array}{l}33.0 \\
12.7\end{array}$ \\
\hline $\begin{array}{l}0.0 \\
0.2 \\
0.2\end{array}$ & $\begin{array}{l}0.0 \\
0.2 \\
0.2\end{array}$ & $\begin{array}{l}0.0 \\
0.0 \\
0.2\end{array}$ & $\begin{array}{l}3.2 \\
0.0 \\
0.2\end{array}$ & $\begin{array}{l}2.6 \\
0.7\end{array}$ & $\begin{array}{l}2.5 \\
0.9\end{array}$ & $\begin{array}{l}0.2 \\
3.4 \\
0.2\end{array}$ & $\begin{array}{l}0.9 \\
0.7\end{array}$ & $\begin{array}{l}1.4 \\
\bullet .5\end{array}$ & $\begin{array}{l}0.5 \\
0.0\end{array}$ & $\begin{array}{l}0.2 \\
\bullet .7\end{array}$ & $\begin{array}{l}\bullet .2 \\
\bullet .2\end{array}$ & $\begin{array}{l}0.0 \\
0.5\end{array}$ & $\begin{array}{l}0.0 \\
0.2\end{array}$ & $\begin{array}{l}0.7 \\
0.2\end{array}$ & $\begin{array}{l}0.0 \\
0.0\end{array}$ & $\begin{array}{l}0.7 \\
0.5\end{array}$ & $\begin{array}{l}0.2 \\
0.0\end{array}$ & $\begin{array}{l}0.4 \\
1.2\end{array}$ & $\begin{array}{l}0.2 \\
0.0\end{array}$ & $\begin{array}{l}0.0 \\
0.7\end{array}$ & $\begin{array}{l}0.2 \\
0.4\end{array}$ & $\begin{array}{l}0.6 \\
0.0\end{array}$ & $\begin{array}{l}2.0 \\
0.9\end{array}$ \\
\hline 35.6 & 27.7 & $\begin{array}{l}24.5 \\
9.2\end{array}$ & 31.8 & 30.2 & 23.5 & $\begin{array}{l}22.2 \\
4.8\end{array}$ & 24.8 & 22.4 & 17.2 & 28.7 & 43.0 & 32.4 & 20.6 & 27.9 & 28.3 & 33.3 & 29.8 & 33.8 & 30.2 & 26.4 & 35.9 & 5.5 & 27.4 \\
\hline 0.5 & & 0.5 & & & & & & & & & & & & & & & & & & & & & \\
\hline 4.5 & 1.7 & 0.7 & - 2 & .4 & 0.9 & 1.4 & 1.2 & 0.0 & ๑. 2 & $\bullet .0$ & $\bullet .9$ & 0.5 & 0.7 & 0.2 & 0.5 & 0.7 & 0.4 & 1.8 & 0.7 & - 2 & 1.7 & 0.0 & 0.0 \\
\hline $\begin{array}{l}4.3 \\
\bullet .2\end{array}$ & $\begin{array}{l}0.6 \\
0.2\end{array}$ & $\begin{array}{l}1.7 \\
0.2\end{array}$ & 0.0 & 0.7 & $\begin{array}{l}0.5 \\
1.4\end{array}$ & 0.5 & $\begin{array}{l}0.0 \\
0.2 \\
4.2\end{array}$ & 0.5 & - 2 & $\bullet .2$ & $\bullet .5$ & 1.2 & - .2 & 0.0 & $\begin{array}{l}0.2 \\
2.3\end{array}$ & 0.2 & 0.0 & •.6 & $\begin{array}{l}\bullet .0 \\
\bullet .2\end{array}$ & - 2 & •.6 & $\begin{array}{l}0.0 \\
24.3 \\
40.0\end{array}$ & $\begin{array}{l}0.0 \\
0.2\end{array}$ \\
\hline & $\begin{array}{l}11.8 \\
15.1\end{array}$ & 25.0 & & $\begin{array}{l}6.0 \\
13.2\end{array}$ & & 35.3 & & & & & & $\begin{array}{l}4.6 \\
3.4\end{array}$ & 25.3 & $\begin{array}{l}0.5 \\
11.6\end{array}$ & $\begin{array}{l}8.9 \\
17.4\end{array}$ & $\begin{array}{l}3.1 \\
17.9\end{array}$ & & & & & & 12.4 & \\
\hline 0.9 & $\bullet .2$ & & & & & & 0.5 & & 0.2 & & & & 0.5 & & & & 4.5 & $1 . \bullet$ & $\bullet .5$ & 0.2 & & & 0.9 \\
\hline 5.2 & $\begin{array}{l}1.9 \\
0.4\end{array}$ & 1.0 & 2.1 & $\begin{array}{l}0.2 \\
2.4\end{array}$ & $\begin{array}{l}0.2 \\
0.2\end{array}$ & 0.7 & 0.5 & $\begin{array}{l}0.7 \\
0.7 \\
0.5\end{array}$ & $\begin{array}{l}0.2 \\
0.2 \\
10.1\end{array}$ & $\begin{array}{l}0.0 \\
\bullet .7\end{array}$ & $\begin{array}{l}.2 \\
\bullet .2\end{array}$ & $\bullet .0$ & $\begin{array}{l}\bullet .7 \\
2.5\end{array}$ & $\begin{array}{l}\mathbf{0 . 0} \\
\mathbf{0 . 5} \\
1.4\end{array}$ & 0.9 & $\begin{array}{l}\bullet .5 \\
2.6\end{array}$ & 0.8 & $\begin{array}{l}1.6 \\
\bullet .2\end{array}$ & $\begin{array}{l}\bullet .5 \\
0.2 \\
0.5\end{array}$ & & 1.3 & & 1.8 \\
\hline $\begin{array}{l}1.4 \\
1.4\end{array}$ & 0.8 & $\begin{array}{l}1.7 \\
0.5\end{array}$ & $\begin{array}{l}1.5 \\
2.2\end{array}$ & 4.4 & $\begin{array}{l}9.4 \\
2.3\end{array}$ & $\begin{array}{l}2.4 \\
\bullet .2\end{array}$ & $\begin{array}{l}14.2 \\
2.8\end{array}$ & $\begin{array}{l}1.2 \\
0.7\end{array}$ & $\begin{array}{l}\text { 0. } 2 \\
\text { 0.5 }\end{array}$ & $\begin{array}{l}1.5 \\
\bullet .5\end{array}$ & $\begin{array}{l}0.9 \\
0.9\end{array}$ & 7.0 & 1.2 & $\begin{array}{l}4.7 \\
\text { ○. } 7\end{array}$ & $\begin{array}{l}4.1 \\
1.4\end{array}$ & 2.1 & $\begin{array}{l}2.2 \\
1.4\end{array}$ & $\begin{array}{l}0.2 \\
0.6\end{array}$ & $\begin{array}{l}\bullet .5 \\
2.0\end{array}$ & $\begin{array}{l}13.6 \\
1.6\end{array}$ & $\begin{array}{l}13.3 \\
5.9\end{array}$ & & $\begin{array}{l}5.9 \\
2.2\end{array}$ \\
\hline 2.7 & 1.1 & & 10.8 & 3.3 & 15.5 & 0.5 & 5.2 & 13.6 & 6.2 & 12.4 & 5.1 & 0.7 & & 2.3 & 2.3 & 0.7 & 13.9 & 9.6 & 13.4 & 3.0 & 4.0 & 5.7 & 13.1 \\
\hline 4.1 & 6.1 & 0.0 & 4.5 & 2.4 & 3.0 & 0.0 & 2.4 & $\bullet .2$ & 0.0 & 0.7 & 1.2 & - 2 & - .2 & $\bullet .5$ & 1.1 & 0.0 & $\bullet .0$ & $\bullet .6$ & $\bullet .0$ & $\bullet .5$ & 1.5 & 0.0 & 0.0 \\
\hline$\bullet .2$ & 0.2 & & - .2 & & & & & & & & & & & & & & & & - .2 & & & & \\
\hline 4.3 & 1.3 & e. 5 & 13.3 & 3.3 & 17.8 & 0.7 & 8.0 & 14.3 & 6.7 & 12.9 & 6.1 & e.7 & $\bullet .0$ & 3.0 & 3.7 & $\bullet .7$ & 15.3 & 10.2 & 15.6 & 4.7 & 9.9 & 5.7 & 15.3 \\
\hline 11.8 & 31.5 & 28.2 & 16.8 & 29.6 & 27.6 & 39.1 & 23.1 & 17.4 & 17.7 & 15.1 & 7.5 & 15.7 & 30.2 & 21.6 & 34.92 & 26.9 & 22.8 & 13.3 & 17.8 & 18.5 & 24.5 & 18.1 & 23.9 \\
\hline $32 . \bullet$ & 12.4 & 16.4 & 27.9 & 14.8 & 17.1 & 1.4 & 22.0 & 27.4 & 27.1 & 29.3 & 35.2 & 28.8 & 14.0 & 23.4 & 7.81 & 17.9 & 22.3 & 30.8 & 27 & 26.4 & 20.6 & 26.7 & 21.2 \\
\hline 5.1 & 26.5 & 23.2 & 2.6 & 22.4 & 8.1 & 37.9 & 11.8 & 2.2 & 8.1 & 1.5 & $\bullet .9$ & 10.7 & 26. & 14.2 & 28.82 & 21.5 & 5.82 & 2.1 & 1.6 & 10.1 & 11.6 & 9.1 & 6.7 \\
\hline 0.9 & 0.3 & 0.4 & 0.9 & - 4 & 0.7 & 0.0 & 0.7 & 0.9 & 0.8 & 0.9 & $1 . \bullet$ & 0.7 & 0.4 & 0.6 & 6.2 & 0.5 & 0.8 & 0.9 & 0.9 & 0.7 & 0.6 & 0.7 & 0.8 \\
\hline 5.9 & 3.4 & 1.7 & e. 5 & 1.6 & 4.4 & 8.3 & 8.3 & •.6 & $\bullet .3$ & 0.9 & 3.5 & 2.3 & 1.4 & 0.6 & 4.2 & 1.9 & $\bullet .5$ & 3.5 & 1.2 & 1.1 & 2.8 & 78.6 & 1.4 \\
\hline $\begin{array}{l}\text { fL } \\
\text { ew }\end{array}$ & $\begin{array}{l}\mathrm{mL} \\
\mathrm{w}\end{array}$ & $\begin{array}{l}\mathrm{fL} \\
\mathrm{mw}\end{array}$ & $\begin{array}{l}\mathrm{mL} \\
\mathrm{vw}\end{array}$ & $\begin{array}{l}\mathrm{crsL} \\
\mathrm{w}\end{array}$ & $\begin{array}{l}\mathrm{mU} \\
\mathrm{vw}\end{array}$ & $\begin{array}{l}\mathrm{mU} \\
\mathrm{w}\end{array}$ & $\begin{array}{l}\mathrm{mU} \\
\mathrm{w}\end{array}$ & $\begin{array}{l}\text { crsL } \\
\text { w }\end{array}$ & $\begin{array}{l}\mathrm{mL} \\
\mathrm{w}\end{array}$ & $\begin{array}{l}\mathrm{mU} \\
\mathrm{mw}\end{array}$ & $\begin{array}{l}\mathrm{fU} \\
\mathrm{vw}\end{array}$ & $\begin{array}{l}\mathrm{fL} \\
\mathrm{mw}\end{array}$ & $\begin{array}{l}\text { fU } \\
\mathrm{w}\end{array}$ & $\begin{array}{l}\mathrm{mU} \\
\mathrm{w}\end{array}$ & $\begin{array}{l}\mathrm{mL} \\
\mathrm{w}\end{array}$ & $\begin{array}{l}\text { fU } \\
\text { w }\end{array}$ & $\begin{array}{l}\mathrm{mU} \\
\mathrm{w}\end{array}$ & $\begin{array}{l}\text { fU } \\
\text { vw }\end{array}$ & $\begin{array}{l}\text { fU } \\
\text { w }\end{array}$ & $\begin{array}{l}\text { fU } \\
\text { mw }\end{array}$ & $\begin{array}{l}\text { fU } \\
\text { w }\end{array}$ & $\begin{array}{l}\mathrm{crsL} \\
\mathrm{p}\end{array}$ & $\begin{array}{l}\mathrm{mU} \\
\mathrm{vw}\end{array}$ \\
\hline
\end{tabular}

diagenetic matrix (epimatrix). It appears as small face to face aggregates, and embedded in syntaxial quartz cements. It is possible to distinguish two precipitate phases: (1) an earlier phase, at the base of the succession and (2) a later one, developing towards the top. The earlier kaolinite occupies intergranular primary pores. It is a poorly developed face to face vermicular kaolinite (10 $20 \mu \mathrm{m}$ in size), commonly replaced by carbonate cements (Fig. 4g). This means that the origin of early kaolinite is related to the eodiagenesis, and promoted by warm and wet continental environment (i.e. Worden and Morad 2003). The younger kaolinite phase fills secondary pores generated by the dissolution of carbonates. Plates of this kaolinite are larger (about $40 \mu \mathrm{m}$ ). Petrographic evidences suggest an origin for young kaolinite associated with telodiagenesis by the influx of meteoric waters during uplift (i.e. Emery et al. 1990; Ketzer et al. 2003; Worden and Morad 2003). At this stage of kaolinite generation, replacements of micas (already deformed by mechanical compaction), occurred. 


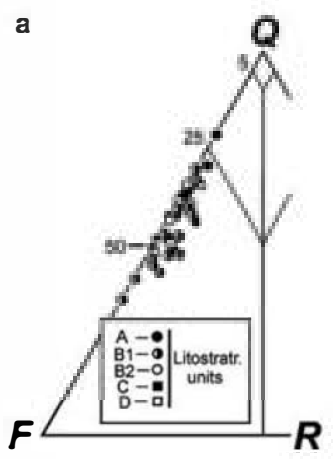

b

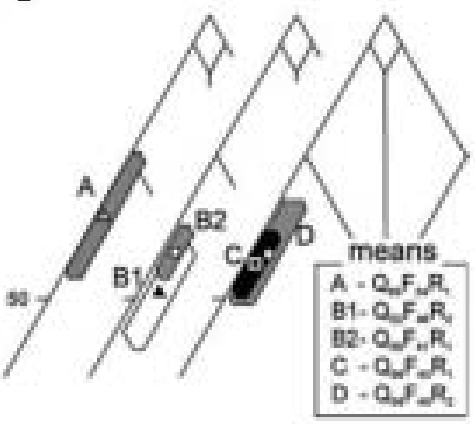

Fig. 3 Sandstone composition of Buntsandstein from northwestern Iberian Chain (Albendiego and Páhmaces de Jadraque sections). a Plot in a QFR ternary diagram (after Pettijohn et al. 1973). b Means and standard deviation fields from each lithostratigraphic unit. Petrographic parameters were calculated from data in Table 1

Illite is very scarce. It appears as local pore lining around detrital grains, generated during early diagenesis. However, no replacements of kaolinite by illite have been observed, as occurs in other depocentral areas (Marfil and Buendia 1980; Arribas 1984, 1987).
The generation of authigenic illite at the expense of kaolinite and $\mathrm{K}$-feldspar has been described by several authors (Bjørlykke 1980; Ehrenberg and Nadeau 1989; Bjørlykke et al. 1995; Chuhan et al. 2000, 2001). These authors consider that this reaction takes place during late diagenesis in a relative close system at $120^{\circ} \mathrm{C} 140^{\circ} \mathrm{C}$, and at burial depths greater than $3.7 \mathrm{~km}$ (Chuhan et al. 2000). However, in the analyzed sandstones significant illitization has not been observed, and still mainly $\mathrm{K}$ feldspar and kaolinite coexist. This situation implies that Buntsandstein deposits have not reached $3.7 \mathrm{~km}$ during burial.

\section{Secondary porosity}

Porosity is very variable (trace to $17.8 \%$, Table 1 ), the maximum occurring in thick amalgamated sandstone bodies (compare values in Table 1 and Pálmaces section in Fig. 2). Porosity is mainly secondary in origin, as evidenced by the presence of corroded grains, intraconstituent pores, inhomogeneity of packing and partial
Fig. 4 a Quartz cement ([Q]) around detrital grains including coatings of hematite and impurities. Primary porosity (P1) is also observed (crossed nicols). b SEM image showing euhedral overgrowth of quartz ([Q]). c Quartz cement ([Q]) postdating euhedral $\mathrm{K}$-feldspar cement ([FK]) (crossed nicols). d SEM image showing dolomite cement ([Dol]) including a euhedral grain of $\mathrm{K}$-feldspar (FK). e K-feldspar cement $([F K])$ in fractures on lower left grain. Dolomite cement ([Dol]) occludes porosity completely (el crossed nicols. $22 \mathrm{CL}$ image of $\mathrm{cl}$ ). Note grain fractures on detrital $\mathrm{K}$-feldspar grains in $\mathrm{CL}$ image, and the lack of dolomite luminescence, except for the last stage of cementation (lower right). $\mathbf{f}$ High values of intergranular volume occupied by dolomite ([Dol] $)$ and $\mathrm{K}$-feldspar cements ([FK]) (cressed nicols). g Early kaolinite pore filling ([Kaol]) replaced by carbonate cement. h 1 , General view of a type I sandstone. Note bigh values of intergranular volume (secondary intergranular porosity, P2). 2, Highly compacted framework from type II sandstones. Note the low intergranular volume. Scale bar in all microphotographs $0.2 \mathrm{~mm}$
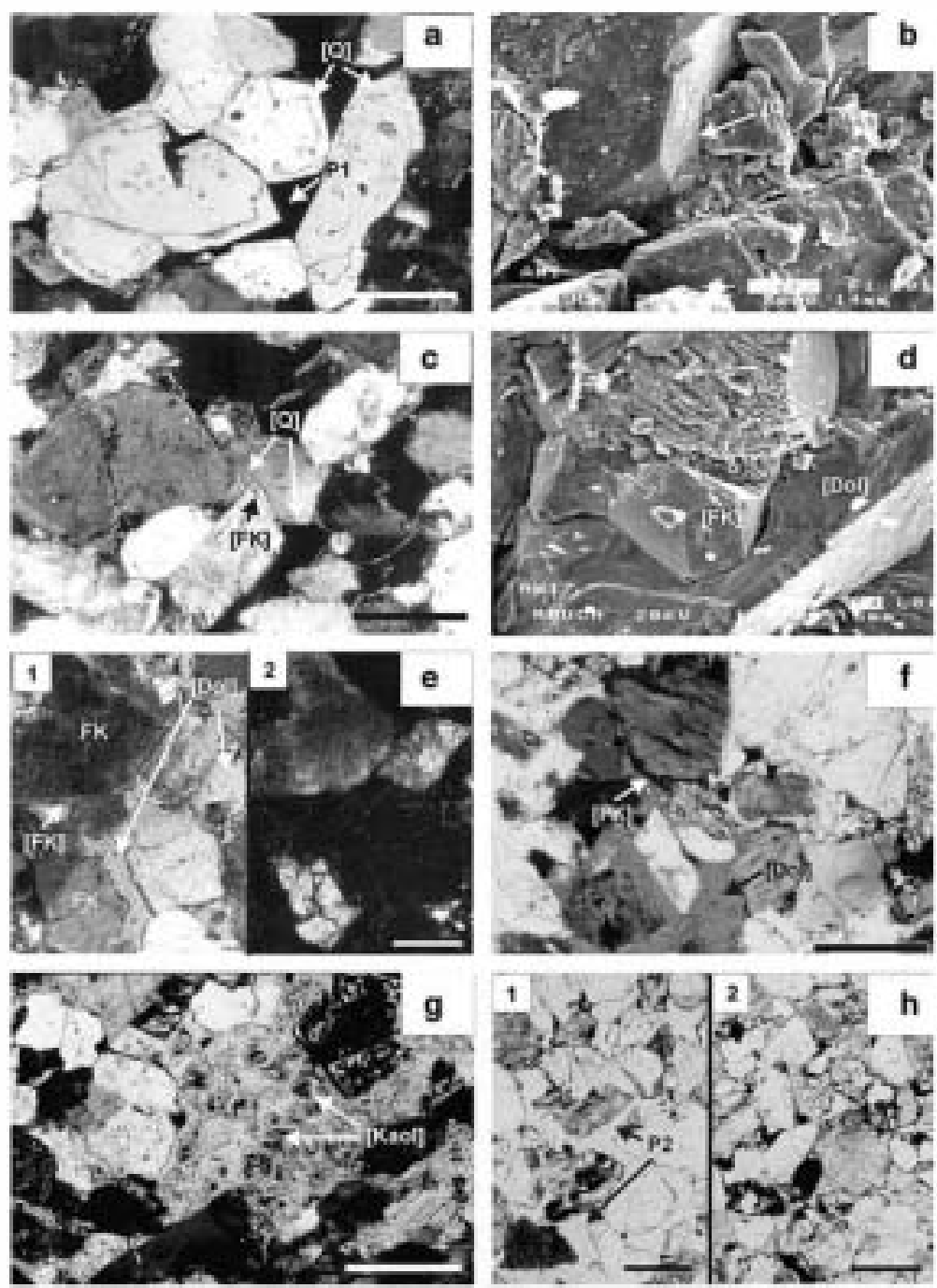
dissolution (Schmidt and McDonald 1979b). Intergranular, oversized and intragranular porosity have all been identified, originating mainly from dissolution of carbonate cements (mean of $7.1 \%$ ) and $\mathrm{K}$-feldspar grains (mean of $3 \%$ ). K-feldspar dissolution (total or partial) is very common and is the second most important genetic type of porosity. There are occasional occurrences of rock fracture porosity. Carbonate cement and Kfeldspar dissolution may be accounted for by the circulation of meteoric fresh waters during a telodiagenetic stage (Bjørlykke 1980, 1983; Arribas and Soriano 1984).

\section{Diagenetic stages and sequence of processes}

A chronological order of diagenetic processes can be established as shallow burial, deep burial and uplift, on the basis of textural features of cements and their interrelationships (Fig. 5). This succession can be related to the following sequence of processes that characterizes the three diagenetic stages (eodiagenesis, mesodiagenesis and telodiagenesis) according to the criteria proposed by Choquette and Pray (1970), Schmidt and McDonald (1979a, b) and Worden and Burley (2003). The first two stages (eodiagenesis and mesodiagenesis) refer to burial stages and are equivalent to those proposed by Machel (1999), as shallow burial, intermediate burial and deep burial.

During eodiagenesis the diagenetic sequence mainly includes: (1) Illite pore lining, (2) Fe-oxides, (3) early kaolinite pore filling and replacements, (4) K-feldspar overgrowth and (5) poikilitic dolomite. The last two cements are widely developed, whereas the first two are scarce and only occur locally. This mineral succession implies that the nature of the pore water underwent considerable change during early eodiagenesis, evolving from variable acidic/alkaline to alkaline conditions for the latest eodiagenetic cements. This evolution favors the growth of $\mathrm{K}$-feldspar cement and implies an increase in $\mathrm{K}^{+} / \mathrm{H}^{+}$ratio in pore waters (i.e. Garrels and Christ 1965; Bjørlykke et al. 1995). Mechanical compaction reduced the intergranular volume in sandstones where dolomite was not precipitated. Chronologically, eodiagenesis may be associated with Buntsandstein, Muschelkalk, Keuper and probably early Jurassic

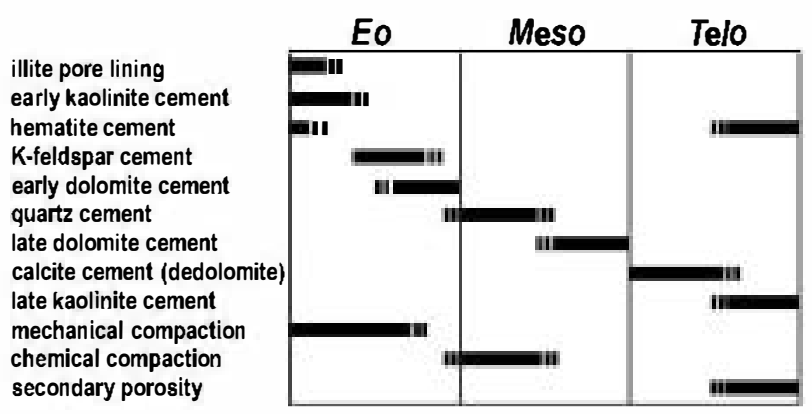

Fig. 5 Chronology of main diagenetic processes and products ascribed to the eodiagenesis, mesodiagenesis and telodiagenesis stages deposition, given the alkaline character of the sabkha/ shallow marine sedimentary environments during the Triassic Jurassic (Marfil and Buendia 1980; Arribas 1984, 1987).

Mesodiagenesis is not intense and is characterized by (6) quartz overgrowth followed by (7) scarce late dolomite cements. Mesodiagenesis probably occurred during the Jurassic. The absence of Jurassic deposits beneath a sharp erosional unconformity at the base of Lower Cretaceous sediments makes the evaluation of the maximum depth reached during mesodiagenesis a difficult task. The thickness of Jurassic sediments towards the East of the study area is estimated around $400 \mathrm{~m}$ (IGME 1981). However, a greater depth of burial for Buntsandstein deposits must be considered by (a) the uncertainty of the thickness of eroded Jurassic before Lower Cretaceous deposition, and (b) by burial depths $(<1.5 \mathrm{~km})$ deduced from mineral reactions and cements.

During telodiagenesis, the influx of meteoric water triggered several processes such as (8) generation of secondary porosity by carbonate and $\mathrm{K}$-feldspar dissolution, (9) kaolinite pore filling, and (10) calcitization and cementation by $\mathrm{Fe}$-oxides. These processes occurred under oxidizing conditions and thus can be related to uplift during Lower Cretaceous and during Tertiary inversion of the basin. During the Lower Cretaceous, Buntsandstein deposits reached $70 \mathrm{~m}$ below the surface. This figure corresponds to the thickness of Muschelkalk and Keuper sediments in the study area. Tertiary inversion produced the surface exposure of Buntsandstein deposits.

\section{Diagenetic model: discussion}

The main diagenetic paths can be analyzed through primary porosity reduction by compaction and cementation processes (COPL and CEPL, respectively; Lundegard 1992) (Fig. 6a). The contrast between COPL and CEPL values reveals the presence of two types of sandstones (type I and II) with different values of intergranular volume (Fig. $4 \mathrm{~h}$ and Table 1).

Type I sandstones present high intergranular volume (from $39.1 \%$ to $24.4 \%$, Table 1 ) represented by cements (dolomite and K-feldspar) and in some cases by secondary porosity. The ICOMPACT (Lundegard 1992) in type I sandstones is $<\mathbf{0 . 5}$, indicating dominance of cementation processes in primary porosity loss. This is consistent with the presence of early carbonate cements in these sandstones, resulting in (1) loss of primary porosity and (2) inhibition of compaction (COPL values $<22 \%$ ).

Type II sandstones are characterized by high compactional porosity loss (from $17.1 \%$ to $35.2 \%$ ) and present low intergranular volume (from $4.1 \%$ to $27.6 \%$ ). The ICOMPACT values of these sandstones range from 0.5 to 1 , indicating that porosity loss was caused mainly by compaction (Lundegard 1992). Inhomogeneity of packing is very common in association with intergranular secondary porosity. This suggests that compaction 

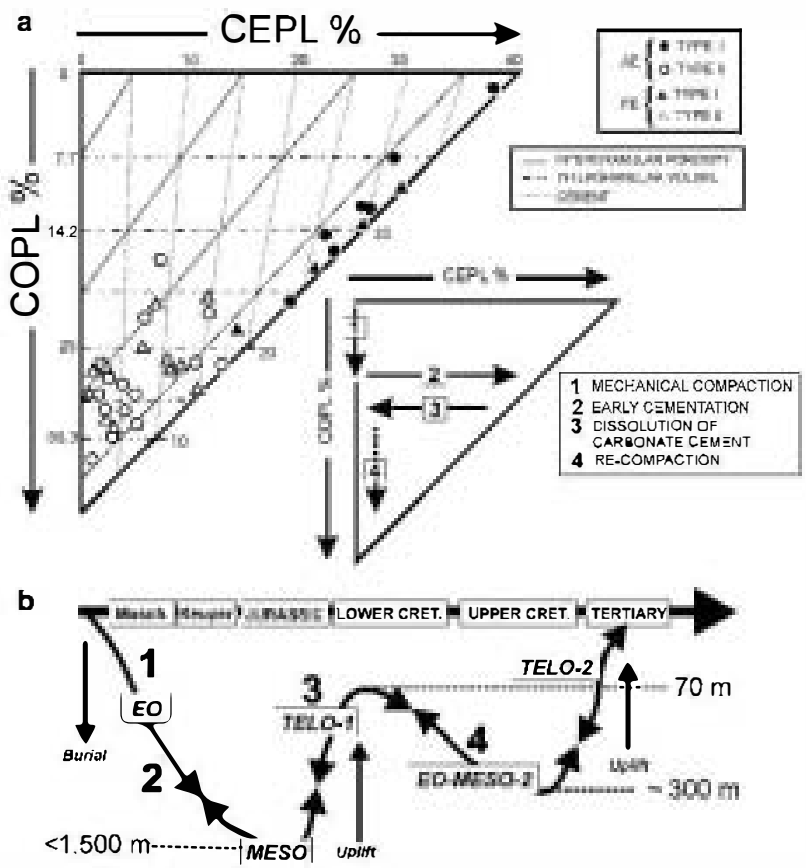

Fig. 6 a Lundegard (1992) diagram showing paths in porosity reduction by compaction and cementation. In this diagram two types of sandstones can be recognized. Type I sandstones (sølid symbels) maintain bigh intergranular volume consisting of cements and in some cases secondary porosity. Type II sandstones (h॰lløw $s y m b \bullet l s$ ) are characterized by high compactional porosity loss, exhibiting low values of intergranular volume. Type II sandstones are the result of dissolution and re-compaction of type I sandstones. Four diagenetic stages are deduced: (1) Loss of porosity by early mechanical compaction; (2) Early cementation (K-feldspar and dolomite); (3) dissolution of cements and K-feldspar; (4) re-compaction. b Scheme showing the deduced timing of diagenetic processes, diagenetic stages and uplift during basin inversion

postdates cement dissolution processes, and hence that type II sandstones are the result of dissolution and subsequent re-compaction of type I sandstones.

This hypothesis postulates porosity reduction in four stages (Fig. 6a): (1) Loss of primary porosity by early mechanical compaction; (2) early cementation (mainly by K-feldspar and dolomite); (3) dissolution of dolomite cement and K-feldspar; and (4) framework collapse by re-compaction.

The diagenetic trend implies an intermediate telodiagenetic phase in which the main dissolution stage occurs. The influx of meteoric waters during Lower Cretaceous fluvial sedimentation has been invoked by several authors to explain telodiagenetic processes in the Buntsandstein (Arribas and Soriano 1984). The Lower Cretaceous unconformity originated during the second rifting cycle in the Iberian Chain (Salas et al. 2001). This regional unconformity is best developed toward the Western margin of the Chain, where low subsident Triassic areas are located (Fig. 1). In the study area, the Lower Cretaceous unconformity is located on Keuper deposits $70 \mathrm{~m}$ above Buntsandstein sandstones, underlining the great erosion process by the absence of Jurassic deposits. The spatial relationship of this unconformity with the Triassic Basin suggests that the marginal area was the main recharge area for meteoric waters during Lower Cretaceous fluvial deposition. Fresh water influx produced a mechanical instability of sandstone framework by dissolution of cements and replacements. Thus, the sandstone framework collapsed by compaction at a later burial stage associated with Cretaceous sedimentation. The collapse of the sandstone framework is therefore considered to predate the Alpine inversion of the basin (Fig. 6b). Depth of this later burial stage can be estimated as at least $300 \mathrm{~m}$, that is the thickness of Cretaceous plus Palaeogene succession in the study area (IGME 1981).

The observed diagenetic processes are in good agreement with the results reported by other authors in depocenter areas of the Iberian Chain (Arribas 1984; Marfil et al. 1977; Marfil and Buendia 1980). Eodiagenetic processes are similar in both marginal and depocentral areas. This means that these processes were generated at relatively shallow depths. However, the two areas differ substantially in mesodiagenetic processes, which are less intense in marginal than in depocentral areas. Quartz cement is prominent in depocentral zones (mean $28 \%$, Arribas 1987) but scarce in marginal zones (generally $<1 \%$ ). Also, illitization of feldspar (epimatrix) generated in this stage is widely developed in depocentral areas (Arribas 1987; Marfil and Buendia 1980), but absent in marginal areas. These data suggest that depocenter areas reached greater burial depths and temperatures than marginal ones, following Chuhan et al. (2000) and Walderhaug et al. (2001) deductions. Finally, telodiagenetic processes are similar in both zones, although they seem to be more intense in marginal areas than in depocentral ones. This idea is supported by the presence of collapsed framework by dissolution processes in sandstones of marginal areas. During the Lower Cretaceous fluvial deposition the marginal areas of the basin acted as meteoric water recharge, and thus meteoric fresh waters penetrated these zones more readily producing intense dissolution processes.

\section{Conclusions}

Diagenetic processes in sandstones from the Buntsandstein in a slowly subsiding, marginal Triassic Basin in the Iberian Chain have been identified, evaluated and ordered chronologically. These processes have been grouped in the three classic diagenetic stages (eodiagenesis, mesodiagenesis, and telodiagenesis; Choquette and Pray 1970).

Eodiagenesis is characterized by a sequence of early cements (mainly illite pore lining, kaolinite pore filling, $\mathrm{K}$-feldspar, and poikilitic dolomite) that inhibited compaction. This sequence reveals an evolution of eodiagenetic waters in shallow depths from fresh to alkaline waters to produce the last two cements (K-feldspar and early dolomite). This succession of diagenetic phases 
may be contemporaneous with deposition of Muschelkalk, Keuper and possibly early Jurassic deposits.

There is very little development of mesodiagenetic processes, which consist of thin quartz overgrowths and local and scarce dolomite cementation. These cements occur at greater burial depths and could be associated to Jurassic times. Deduced maximum burial depth by diagenetic mineral reactions and cements is less than $1.5 \mathrm{~km}$ approximately, and at low temperatures.

Telodiagenesis is characterized by several processes related to the influx of meteoric waters during the Lower Cretaceous and during Alpine inversion of the basin. The main processes affecting sandstones are dissolution of carbonate and $\mathrm{K}$-feldspar cements, kaolinite porefilling, and calcitization.

The analysis of porosity loss during diagenesis suggests the presence of two types (I and II) of sandstones, distinguished by their amount of intergranular volume. Type I sandstones have an open framework with high intergranular volume, where porosity has been lost mainly through cementation processes (i.e. early dolomite). Type II sandstones are characterized by scarce intergranular volume and major loss of porosity through compaction. Type II sandstones seem to be the result of diagenetic dissolution of early cements of type I sandstones and subsequent re-compaction in an intermediate telodiagenetic stage during Lower Cretaceous fluvial deposition. This assumption is deduced from the regional geological setting given the presence of Lower Cretaceous unconformity. Thus, the western margin of the Chain acted as the main phreatic recharge area to the Triassic deposits during the Lower Cretaceous deposition.

There are some differences in diagenesis between marginal and depocentral zones of the Triassic Basin. Eodiagenetic and telodiagenetic processes are very similar, but probable telodiagenesis seems to be more intense in marginal areas. Mesodiagenetic processes are less significant in marginal sandstones (thin quartz overgrowths and absence of illitization) due to shallower burial during this stage.

This work describes diagenetic processes and products on sandstones from the margin of a rifted basin, and hence our results are of broad interest and applicable on similar worldwide settings. Many of those processes have dramatic consequences on sandstone properties (i.e. reservoir quality) and characterize diagenetic paths on marginal areas of rift basins.

Acknowledgements This study was supported by the Spanish DGICYT through project BTE2001 0026. We would like to thank Dra. C. Taberner, Dr. G. Keller and Dr. H.G. Machel for their comments and suggestions that substantially improved the manuscript.

\section{References}

Arche A, López-Gómez J (1999) Subsidence rates and fluvial architecture of rift-related Permian and Triassic alluvial sediments of the southeast Iberian Range, eastern Spain. IAS Spec Publ 28:283 304 del Muschelkalk de la Rama Aragonesa de la Cordillera Ibérica (provincias de Soria y Zaragoza). Editorial de la Universidad Complutense, Madrid, $354 \mathrm{p}$

Arribas J (1987) Origen y significado de los cementos en las areniscas de las facies Buntsandstein (Rama Aragonesa de la Cordillera Ibérica). Cuad Geol Ibérica 11:535 556

Arribas J, Soriano J (1984) La porosidad en las areniscas riásicas (Rama Aragonesa, Cordillera Ibérica). Estud Geol 40:341 353

Arribas J, Marfil R, De la Peña J (1985) Provenance of Triassic feldspathic sandstones in the Iberian Range (Spain): significance of quartz types. J Sediment Petrol 55:864 868

Aurell M, Melendez G, lóriz F, Bádenas B, Caracuel JE, García Ramos JC, Goy A, Linares A, Quesada S, Robles S, RodríguezTovar FJ, Rosales I, Sandoval J, Suárez de Centi C, Tavera JM, Valenzuela M (2002) Jurassic. In: Gibbons W, Moreno MT (eds) The geology of Spain. Geological Society, London, pp 213253

Beard DC, Weyl PK (1973) Influence of texture on porosity and permeability of unconsolidated sand. Am Assoc Petrol Geol Bull 57/2:349 369

Bjørlykke K (1980) Clastic diagenesis and basin evolution. Rev Instituto Invest Geol 34:21 24

Bjørlykke K (1983) Diagenetic reactions in sandstones. In: Parker A, Sellwood BW (eds) Sediment diagenesis NAT ASI series 115. Reidel, Dordrecht, pp 169213

Bjørlykke K, Aagaard P, Egeberg PK, Simmons SP (1995) Geochemical constraints from formation water analyses from the North Sea and the Gulf Coast Basins on quartz, feldspar and illite precipitation in reservoir rocks. In: Cubitt JM, England WA (eds) The geochemistry of reservoirs. Geological Society, London, Special Publication 86:33 50

Burley SD, Mullis J, Matter A (1989) Timing diagenesis in the Tartan Reservoir (UK North Sea): constraints from combined cathodoluminiscence microscopy and fluid inclusion studies. Mar Petrol Geol $6: 98104$

Chayes F (1952) Notes of the staining of potash feldspar with sodium cobaltinitrite in thin section. Am Mineral 37:337 340

Choquette PW, Pray LC (1970) Geologic nomenclature and classification of porosity in sedimentary carbonates. Am Assoc Petrol Geol Bull 54(2):207 250

Chuhan A, Bjørlykke K, Lowrey C (2000) The role of provenance in illitization of deeply buried reservoir sandstones from Haltenbanken and north Viking Graben, offshore Norway. Mar Petrol Geol 17:673 689

Chuhan A, Bjørlykke K, Lowrey C (2001) Closed-system burial diagenesis in reservoir sandstones: examples from the Garn Formation at Haltenbanken area, offshore mid-Norway. J Sediment Res 71:15 26

Ehrenberg SN, Nadeau PH (1989) Formation of diagenetic illite in sandstones of the Garn Formation, Haltenbanken, mid-Norwegian continental shelf. Clay Miner 24:233 253

Emery D, Myers RJ, Young R (1990) Ancient subaerial exposure and freshwater leaching in sandstones. Geology 18:1178 1181

Garrels RM, Christ ChL (1965) Solutions, minerals and equilibria. Harper and Row, New York, $450 \mathrm{p}$

Giles MR, Stevenson S, Martin SV, Cannon SJC, Hamilton PJ, Marshall JD, Samways GM (1992) The reservoir propierties and diagenesis of the Brent Group: a regional perspective. In: Morton AC, Haszeldine RS, Giles MR, Brown S (eds) Geology of the Brent Group. Geological Society, London, Special Publication 61:289 327

Gluyas JG, Grant SM, Robinson A (1993) Geochemical evidence for a temporal link control on sandstone cementation. In: Horbury AD, Robinson AG (eds) Diagenesis and basin development. Am Assoc Petrol Geol Studies in Geology 36:23 33

Groot K De (1967) Experimental dedolomititation. J Sediment Petrol 37:1216 122

Haszeldine RS, Samson IM, Cornford C (1984) Dating diagenesis in a petroleum basin: a new fluid inclusion method. Nature 307:354 357 
Heald MT (1959) Significance of stylolites in permeable sandstones. J Sediment Petrol 29:251 253

Houseknecht DW (1987) Assessing the relative importance of compaction processes and cementation to reduction of porosity in sandstones. Am Assoc Petrol Geol Bull 71:633 642

IGME (1981) Mapa Geológico de España, E: 1/50.000. Hoja n 461, Sigüenza

Ketzer JM, Morad S, Nystuen JP, De Ros LF (2003) The role of the Cimmerian Unconformity (Early Cretaceous) in the kaolinitization and related reservoir-quality evolution in Triassic sandstones of the Snorre Field, North Sea. In: Worden RH, Morad S (eds) Clay mineral cements in sandstones. Int Assoc Sedimentol Spec Publ 34:361 382

Lindholm RC, Finkehnan RB (1972) Calcite staining; semiquantitative determination of ferrous iron. J Sediment Perol 42:239 245

Lundegard PD (1992) Sandstone porosity loss A "Big Picture" view of the importance of compaction. J Sediment Petrol $62: 250260$

Machel HG (1985) Cathodoluminescence in calcite and dolomite and its chemical interpretation. Geosci Can 12:139147

Machel HG (1999) Effects of groundwater flow on mineral diagenesis, with emphasis on carbonate aquifers. Hydrogeol J 7.94107

Marfil R, Buendía E (1980) La evolución diagenética de los sedimentos detríticos del Pérmico y Triásico del Sondeo de Sigüenza (provincia de Guadalajara). Rev Instituto Invest Geol 34:59 74

Marfil R, Cruz B, de la Peña J (1977) Procesos diagenéticos de las areniscas del Buntsandstein de la Cordillera Ibérica. Cuad Geol Ibérica 4:411 422

Marfil R, Scherer M, Turrero MJ (1996) Diagenetic processes influencing porosity in sandstones from the Triassic Buntsandstein of the Iberian Range, Spain. Sediment Geol 105:203 219

Mitra S, Beard WC (1980) Theoretical models of porosity reduction by pressure solution for well-sorted sandstones. J Sediment Petrol 50:1347 136•

Morad S, Marfil R, de la Peña J (1989) Diagenetic K-feldspar pseudomorphs in the Triassic Buntsandstein sandstones of the Iberian Range, Spain. Sedimentology 36:635 650

Morad S, Al-Aasm IS, Ramseyer K, Marfil R, Aldahan AA (1990) Diagenesis of carbonate cements in Permo Triassic sandstones from the Iberian Range, Spain: evidence from chemical composition and stable isotopes. Sediment Geol 67:281295
Morad S, Al-Aasm IS, Longstaffe FJ, Marfil R, De Ros LF, Johansen H, Marzo M (1995) Diagenesis of a mixed siliciclastic/ evaporitic sequence of the Middle Muschelkalk (Middle Triassic), the Catalan Coastal Range, NE Spain. Sedimentology 42:749 768

Pettijohn FJ, Potter PE, Siever R (1973) Sand and sandstones. Springer, Berlin Heidelberg New York, $618 \mathrm{p}$

Rittenhouse $G$ (1971) Mechanical compaction of sands containing different percentages of ductle grains: a theoretical approach. Am Assoc Petrol Geol Bull 55:92 96

Salas R, Guimerà J, Mas R, Martín-Closas C, Meléndez A, Alonso A (2001) Evolution of the Mesozoic Central Iberian Rift System and its Cenozoic inversion (Iberian Chain). In: Cabazza W, Robertson AHFR, Ziegler P (eds) Peri Tethyan Rift/Wrench Basins and Passive Margins Mémoires du Muséum National d'Histoire Naturelle. Tome 186:145 186

Schmidt V, McDonald DA (1979a) The role of secondary porosity in the course of sandstone diagenesis. Soc Econ Paleontol Mineral Spec Publ 26:175 207

Schmidt V, McDonald DA (1979b) Texture and recognition of secondary porosity in sandstones. Soc Econ Paleontol Mineral Spec Publ 26:209 225

Sopeña A, Sánchez-Moya Y (1997) Tectonic systems tract and depositional architecture of the western border of the Triassic Iberian Trough (central Spain). Sediment Geol 113:245 267

Tucker M (1988) Techniques in sedimentology. Blackwell, Oxford, $394 \mathrm{p}$

Walderhaug - Bjørkum PA, Nadeau PH, Lagnes Quantitative modelling of basin subsidence caused by temperature-driven silica dissolution and reprecipitation. Petrol Geosci 7:107 113

Worden RH, Burley SD (2003) Sandstone diagenesis: the evolution of sand to stone. In: Burley SD, Worden RH (eds) Sandstone diagenesis. Int Assoc Sedimentol Reprint Series 4:3 44

Worden RH, Morad S (2000) Quartz cementation in oil field sandstones: a review of the key controversies. In: Worden RH Morad S (eds) Quartz cementation in sandstones. Int Assoc Sedimentol Spec Publ 29:1 10

Worden RH, Morad S (2003) Clay minerals in sandstones: controls on formation, distribution and evolution. In: Worden RH, Morad S (eds) Clay mineral cements in sandstones. Int Assoc Sedimentol Spec Publ 34:3 41

Zuffa GG (1985) Optical analyses of arenites: influence of methodology on compositional results. In: Zuffa GG (ed) Provenance of arenites. NAT ASI Series, Serie C 148:165 189 